DOI: 10.22559/folklor.1034

folklor/edebiyat, cilt: 25 , sayı: 100, 2019/4

\title{
Arnavutça Konuşma Dilinde Türkizmalar: Kosova Sözlü Tarihi Örneği
}

\author{
Turkisms in Spoken Albanian: \\ Example of Oral History of Kosova
}

\section{Zeqije Xhafçe*}

Öz

Bir sözcüğün farklı bağlam ve durumlarda, farklı dil kesitlerinde farklı anlamlar alabileceği, modern dilbiliminde kanıtlanan bir gerçektir. Kesit dillerini toplum dilbilimine yerleştirmeye çalışan Biber (1994) kesit dillerinin yazılı ve sözlü olmak üzere de iki ayrı sınıfa ayrılmasının önemini vurgularken birçok toplum dilbilimcinin konuşma dilinin dilin temel şekli olduğunu savunduğunu söylemektedir. $\mathrm{Bu}$ tespitlerin 1şığında, Arnavutça sözcükleriyle değiştirilmesi gereken yabancı sözcükler olarak nitelendirilen ve Türkizma adıyla bilinen sözcüklerin konuşma dilinde ve diğer kesit dillerindeki kullanımı ele alındı. Arnavutça sözvarlığının tarih, kültür ve dil açısından önemli bir parçası olan türkizmaların genel olarak konuşma ve özel olarak diğer kesit dillerindeki kullanımının incelenmesi yapılmadan konumları hakkında doğru bilginin edinemeyeceğini düşünüyoruz. Dolayısıyla, çalışmamızda 100'e yakın konuşmacının yer aldığı Kosova Sözlü Tarihi projesinin videoları esas alınarak, türkizmaların konuşma dilindeki kullanımları incelendi. Toplumdilbilimsel yöntemleri ile türkizmaların kullanım sıklığı, konu odaklı kategorilerdeki dağılımı ele alındı, nicel ve nitel incelemesi yapıldı. 19. yüzyılın ilk yarısından bu yana pürizm konusu olan türkizmaların Arnavutçadaki güncel konumu

Doktora adayı, Öğr.Gör., Priştine Üniversitesi, Filoloji Fakültesi, Şarkiyat Bölümü, zekije.xhafqe@ uni-pr.edu. ORCID 0000-0001-2345-6789. 
tespit edilmeye çalışıldı. Arnavutçada yer alan türkizmaların ister güçlü bir deyiş/ biçem aracı olarak kullanımı ister Arnavut sözvarlığının aktif unsuru olup olmadığ1 modern dilbilim yöntemleri uygulanarak araştırıldı.

Anahtar sözcükler: türkizm, ödünçlemeler, toplum dilbilimi, kesit diller, biçem, Kosova Sözlü Tarihi

\begin{abstract}
Recent studies on styles and registers have proved that a word can have different meanings in different contexts and situations. Biber (1994), who tries to place registers in social linguistics, emphasizes the importance of splitting registers into two distinct classes: written and spoken, while many sociologists argue that spoken language is the basic form of the language. This paper deals with Turkish loaned words of Albanian language known as Turkizms in the context of forementioned findings. We think that one cannot obtain accurate information about Turkisms' status in Albanian lanugage without examining their use of speech in different domains, styles and registers. Therefore, in our study, the use of Turkisms in spoken language was examined based on the videos of the Kosovo Oral History project, which includes nearly 100 speakers. We have analized Turkism's distribution and usage among different varieties of Albanian spoken language by using both quantitative and qualitative methods. Based on obtained results, we have tried to determine the current status of Turkisms which are the subject of purism activities since standardization of Albanian spoken language. We have investigated the use of Albanian turkisms as a mean of expression and style and as an active element of Albanian vocabulary.
\end{abstract}

Keywords: turkisms, loanwords, sociolinguistics, style, register, oral history of Kosovo

\title{
Giriş
}

Çalışmamızın konusu türkizma adıyla bilinen, Türkçenin vasıtasıyla Balkan dillerine giren Türkçe, Arapça ve Farsça kökenli sözcüklerdir. Osmanlı'nın dilinin Balkan topraklarında yüzyıllarca ortak iletişim dili (lingua franca) olması, Arnavutçaya binlerce sözcüğü miras bırakmasına sebep olmuştur. Bugüne kadar, ister Balkan ister batı dünyası dilbilimcilerince Arnavutçadaki Türkçe kökenli sözcükler çeşitli bilimsel açıdan incelenmiştir. Miklosich, Meyer, Boretzky, Dizdari, Sandfeld, Çabej, Jashar-Nasteva, Desnickaya gibi dilbilimciler, bu sözcüklerin sayımını yapıp, dilbilgisel özelliklerini incelemekle kalmayıp kullanım alanlarına göre sınıflandırmaya çalıştılar. Anlambilim bağlamında geleneksel ve mantıksal sınıflandırmaları birçok defa yapıldı. Binlerce kelimenin mutfak, askeri, genel kültür, sanat, hayatın olumlu ve olumsuz durumları, maddi ve maddi olmayan kültür, din, ad bilim gibi farklı kategoriler olmak üzere farklı alanlarda varlığı tespit edildi (Dizdar, 2005); sözlük tanımlarına dayanarak anlambilimsel incelemeleri yapıldı (Xhanari, 2012). Son olarak da Çağdaş Arnavutça Sözlüğünde yer alan bir liste türkizmalar yine sözlükteki tanımlarına dayanarak incelenip artık bu ödünçlemelerin çoğunun özenli dilde kullanılmadı̆̆ı ve özensiz 
dilde kullanıldığı kanıtlanmaya çalışıldı ve bu tür sınırlı kullanımın nedenleri incelendi (Rugova, 2017). Bu varsayımlar, sadece Arnavutçadaki türkizmalar için değil, tüm Balkan dilleri ile alakalı olup benzer sonuçlara varıldı.

Modern dilbilimi teorilerine göre, sözcüklerin anlamsal özellikleri ele alınırken sırf sözlük tanımlarına başvurmanın yetersiz ve bağlam dışında incelenmesinin eksik sonuçlar vereceği savunulmuştur (Wierzbicka, 1999: 11). Dolayısıyla, çalışmamızda diğer incelemelerden farklı olarak türkizmaların sırf sözlükteki tanımlarına göre değil, güncel Arnavutçadaki mevcut kullanımları ele alınarak konumları tespit edilmeye çalışıldı. Çalışmamızda teori kısmında konuşma ve yazı dili arasındaki farklar, kesit dillerinin dil incelemeleri açısından taşıdığ1 önem, türkizmaların kesit dillerinde incelenmesinin önemi, Kosova Sözlü Tarihi (KST) derleminin toplumdilbilimsel özellikleri, türkizmaların KST derleminin toplumdilibilimsel özelliklerine göre incelemesi ve derlemde kaydedilen türkizmalarda ortaya çıkan sözcükselanlamsal olgulara değinildi.

\section{Arnavutçanın bazı dil özellikleri ve türkizmalara karşı dilsel tutum}

Türkizmaların Arnavutçadaki konumlarını anlayabilmek için öncelikle Arnavutçanın kullanım alanı ve değişkelerinden bahsetmek yerinde olur. Arnavutça Gegë ve Toskë olmak üzere iki ana lehçeye ayrılarak gelişmiştir (Demiraj, 2013: 302). Bugüne kadar bulunan en eski Arnavutça kitap 16. yüzyıla aitLatin harfleriyle yazılı"Meshari i Buzukut” adlı dini bir metinden ibarettir (Demiraj, 2013: 324). Bu eserde yer alan türkizmalar şunlardır: dollamë, harami, kallauz, tepsi, türk ve çohe. Krajni'ye göre türkizmaların Arnavutçaya girmesinin ilk dönemi olarak adlandırılan bu dönemde çıkan eserlerdeki türkizmaların sayısı az da olsa ödünçlemelerin dinamiğini gösterir (Krajni, 1965: 280). Bundan sonra on-yirmi yıl aralıklarıyla çeşitli sözlükler ve folklor derlemleri ortaya çıkmıştır. Bu eserlerde, Türkçe kökenli sözcüklerin yabancı sözcük olarak değerlendirildiği ve Arnavutça halk dilinden çıkarılması gerektiği vurgulanmaktadır. (Xhanari, 2012: 21). Bize göre ise aynı dönemde çıkan başka eserlerde türkizmaların sayısının artması aslında, Türkçe kökenli kelimelerin daha o dönemde Arnavutçaya oldukça yerleştiğini ve sayının eserlerin hacmi ve yazılış hedefine göre farklılık gösterdiğini gösterir.

Arnavut yazı dili, 18. yüzyılda iki farklı yönde gelişmektedir. İlk grupta Elbasanlı isimsiz eserler, Dhaskal Todri vs. tarafından yazılan ve çevrilen dini ve eğitim kitapları, diğer tarafta ise Arap alfabesini kullanan ve dini, ilahi ve beşeri konuları ele alan evrensel şiir üreten $\mathrm{Ne}$ zim Frakulla, Muhamet Kyqyku, Hasan Zyko Kamberi gibi yazarların kaleme aldığı eserler mevcuttur (Demiraj, 2013: 337) ${ }^{1}$. 19. yüzyılın ikinci yarısında Arnavut yazı dilinin yayılması büyük bir hız alır. 19. yüzyılın son on yılında ve 20. yüzyılın ilk yarısında işlenmiş bir Arnavut yazı dilinin kullanımı başladı. Yabancı kelimelerden, özellikle de Türkçe ve Yunanca kökenli sözcüklerden temizlenme ve yeni kelimelerle zenginleştirme mekanizmaları geliştirilmeye başladı. 1952 yılında, Toskë lehçesi standart Arnavutça olarak ilan edildi. Bu lehçe tarih boyunca Elba, Yunan ve Latin alfabesi kullanılarak yazıldı. Gegë lehçesinin ise Sırbistan ve Kosova' daki statüsü taşra lehçesi olsa da kullanımı gayet dinamik olan bir lehçedir. Bu lehçe, 1869-1990 yılları arasında gazetecilikte yoğun bir şekilde kullanılmıştır. Günümüzde Latin alfabesi ile yazılırken tarih boyunca Arap alfabesi kullanılarak yazı diline dökülmüştür. ${ }^{2}$ 
Krajni’ye göre, diğer Balkan dillerine kıyasen düşünüldüğü gibi büyük sayıda ödünçlemeye sahip değildir (Krajni, 1965: 279). Arnavutça yazı dilinin çok geç bir dönemde Türkçe kelimelere karşı çok sıkı bir tutum gösterildiğinde hız almış olması, Türkçenin kırsal kesimlerden çok şehirlerde kullanılmış olması, bu durumun en önemli sebepleridir. Bu da, Arnavutçadaki türkizmaların gerçek durumunu incelerken, yazı dilinden çok bu söz varlığının taşıyıcısı olan konuşma diline, halk diline başvurulması gerektiğinin önemli bir kanıtıdır.

Daha geç dönemlerde Arnavutçanın konuşma dilinden yazı diline dönüşmesi ve bir standart dilin oluşturulması çabaları sürerken yabancı sözcüklerden temizleme faaliyetleri de başlıyor. Şöyle ki, Latin alfabesiyle yazılan Arnavutça yazı dili büyük bir titizlikle oluşturulurken de türkizmaların olabildiğince az kullanılmasına dikkat ediliyor. Sözlüklerdeki türkizmaların çoğu 'özensiz dil', 'eskimiş’ olarak işaretleniyor. Günümüzde ise, 1981 y1lında başlatılan 'Fjala shqipe në vend të fjalës së huaj’ adlı proje çerçevesinde halâ Arnavutça kelimelerle değiştirilmesi gereken yabancı kökenli sözcüklerin listesinde bir sürü türkizma yer almaktadır.

\section{Konuşma ve yazı dili arasındaki farklar}

Kesit diller, 'odaklanmanın herhangi ayrıntısında tespit edilebildiğine'(Halliday, 1988: 162) göre çok önemli konulardan birini teşkil etmektedir. Kesit diller son derece yüksek değişkelerden başlayıp bazı orta derece değişkelere kadar yayılabilir. Daha doğrusu özenli ve özensiz dil, konuşma ve yazı dili gibi yüksek değişkelerden tutup karşılıklı konuşma, anlatı, deneme, kompozisyon, roman, bilimsel araştırma ve makaleler gibi orta derece ve psikoloji makalelerindeki metodoloji bölümleri ve gazete başlıkları gibi alt seviye değişkelere kadar oldukça geniş bir alana yayılmaktadır.

Çalışmamızın devamı için kesit dillerini oluşturan konuşma ve yazı dilleri arasında en göze çarpan farkları vurgulamamız gerektiğini düşünüyoruz. Bu iki değişke hakkında doğru olduğu bilinen genellemelerden bahsetmek gerekirse şunu söyleyebiliriz: Yazı dili, konuşma dilinin potansiyel anlamının tümünü içermez. Bürünsel ve ötedil katkılarını dahil etmez. Konuşma ve yazı, belirli miktarda örtüşme göstererek farklı bağlamlarda farklı amaçlarla kullanılır. Bir anlamda farklı gerçekler yaratır. Konuşma ve yazı dilindeki farkları inceleyen Halliday'a göre konuşma ve yazı dili arasındaki farklar şunlardır:

- Yazı dilinin resmiyetine bağlı olarak konuşma dilinin yazı diline kıyasen sözcük yoğunluğu daha düşüktür.Bu bağlamda, mantıken türkizmaların çeşitlilik açısından sayısının daha düşük olacağı, fakat Arnavutçadaki kullanımının gerçek durumunu yansıttığını düşünüyoruz.

- Konuşma ve yazı dili iki farklı tecrübelerimizi temsil etme yoludur. Yazı dili olguları ürün olarak temsil ederken konuşma dili olguları bir süreç olarak temsil eder. Bu yüzden, türkizmaların olay anlatırken mevcudiyetini incelemek sözcük seçimi sırasında konuşmacının kendiliğindenliği açısından farklı sonuçlar vermektedir (Halliday,1989: 92-93).

\section{Türkizmaların kesit dillerinde incelenmesinin önemi}

Kesit dillerinin herbirinde konuşmacı, toplumsal sınıf, kültür, tercihleri, yaşı, eğitimi, cinsiyeti ve toplumdilbilimini ilgilendiren diğer etkenlere bağlı olarak belirli sözcük seçimlerini yapar. Ancak, bu bağlamda 'sözlük birimlerinin konu ile sınırlı olabileceği gibi sözcük seçiminingenelde tek başına belli bir kesit dilini işaretlemediğini’ (Biber, 1994: 34) hatırlatmak gerekir. 
Konuşanların toplumsal özelliklerine göre çeşitli kesitler ve bu kesitlerin kendine has dilleri oluşmaktadır. Aşağıdaki örneklerde de görülebileceği gibi aksham (tr. akşam) kelimesi birçok farklı kesit dilinde kullanılır.

(1) ar. 'e kom fal akshamin' - tr. akşamı kıldım/Akşam namazını kıldım. (forum/özensiz konuşma).

(2) Aksham, mendova, ç'fjalë madhështore. Sonte është tamam aks-

ham. Nuk është as mbremje, assoir, e aq më pak vjeçer por është aksham./ Düşündüm de, akşam nasıl da azametli bir kelime. Bu gece tam anlamiyla bir 'akşam'. Ne 'mbrëmje' ne de 'assoir', 'vjeçer' ise hiç değil. (roman-özenli, edebi dil)

Gördüğümüz gibi aksham sözcüğü, sadece gün içindeki belirli bir vakti değil, dini kesit dilinde 'akşam namazını' belirtmek için de kullanılır. Bir sözcük birimi (türkizma) kesit dilini belirlemese bile, yüksek dereceli değişkelerin her birinde konuşmacılar bağlama ve duruma göre belirli sözcük seçimleri yapar ve bu seçimler arasında, taşıdığı özel anlamlarından dolayı illa ki türkizmaların kullanımı şart olur. Arnavutçada bulunan türkizmaların da bu yüzden değişkeler, konular düzleminde incelenmesi, onların Arnavutçadaki yerini ve konumunu daha kesin ve net bir şekilde belirler. Böyle bir incelemenin uygulanması türkizmaların kullanım alanlarının temsili olacak yeterli miktarda sözcük sıklığı ve çeşitliliği olan bir derlem gerektirir.

'Konuşma dilinin dilin esas ya da 'gerçek' şekli' (Aronoff, 1985: 28) olduğunu vurgulamak gerekirse de son zamanlarda yapılan çalışmalar ışı̆̆ında konuşma ve yazı kesit dillerinin sahip olduğu dilsel özelliklerinin arasında önemli derecede bir örtüşmenin de söz konusu olduğunu unutmamak gerekir. Burada, özenli dil deyince standart değişke, standart değişke deyince de Toskë lehçesi akla gelse de Kosova'da Gegë lehçesinin de resmi konuşmalarda kullanıldığını vurgulamak gerekir. Dolayısıyla, farklı seviyeden birçok değişkenin birbiriyle örtüşmesi söz konusu olabilir. Ayrıca, konuşmacı karşısında bulunan dinleyici veya muhataba göre biçem (style) de değiştirir. Örneğin, bir öğrenci hocasının karşısında daha özenli bir biçemle konuşur. Röportaj yapılan kişi röportaj yapan kişiye göre konuşma biçemini belirler, resmiyetini bir derece artırır ya da azaltır.

Kişinin söz dağarcığındaki çeşitliliğinin onun sosyo-ekonomik konumuna bağlı olarak farklılık gösterdiği de kanıtlanmıştır (Biber, 1994: 333). Günümüzde orta sınıf konuşmacılarının alt sınıf konuşmacılarına kıyasen daha yüksek sözcük çeşitliliğine sahip olduğu tespit edildi. Bu açıdan, türkizmaların farklı biçemlerde kullanımının onların Arnavutça kökenli sözcüklerle değiştirilmesini zorlaştıracağını hatta imkânsız kılacağını gösterir.

\section{4. Çalışmanın amacı, varsayımlar ve sorular}

Çalışmamız, farklı bağlamlarda ve farklı kesit dillerinde gösterdikleri farklı anlamları yüzünden Türkçe kökenli sözcüklerin Arnavutça sözcükleri ile değişemeyeceği fakat gitgide özenli dilden özensiz dile ve özensiz konuşmaya geçtiği varsayımı üzerinde yapılandırılmakta. Çalışmamızın amaçlarından biri Rugova'nın (2017: 225-234) bu varsayımını nicel inceleme yöntemi uygulayarak doğruluğunu tespit etmektir. 
Makedoncada yer alan türkizmalar Friedman'1n (2002: 20) da dediği gibi günümüzde artık özenli (edebi, standard) dilinin özensiz dilden uzak tutulmaması ya da yakın tutulması bu sözcüklerin tekrar gündeme gelmesine neden olduğu ve tekrar canlandığı görülmüştür. Aynı şekilde, Reinkowski (2002: 98-112) de Boşnakçadaki türkizmaların konumunu inceleyen bir çalışmasında bu sözvarlığının çeşitli biçemlerde kullanıldığı için tekrar gündeme geldiğini vurgulamaktadır. Dolayısıyla, bu çalışmada, Arnavut dili ile ilgili bilimsel çalışmalarda defalarca önemli ve güçlü bir biçem/deyiş aracı olarak nitelendirilen türkizmaların üzerinde de aynı şekilde yansıyıp yansımadığı araştırılacaktır.

\section{5. Çalışmada kullanılan inceleme yöntemleri}

Çalışma nicel ve nitel inceleme yöntemleri kullanılarak yapıldı. Türkizmaların anlamına farklı bir açıdan yaklaşıp dil-bağlam ilişkisi ele alındı. Çalışmamız, 2012'den beri "Kosova Sözlü Tarihi-Oral History of Kosova"adı altında yayınlanan sözlü anlatımlardan oluşan derlemeye dayanarak yapıldı. Video şeklinde yayınlanan görüşmeler, transkript üzerinden de takip edildi.

Kullanım sıklığı, dil incelemeleri için dilbilimciler ve bilgisayar uzmanları tarafından geliştirilen Sketch Engine yazılımı kullanılarak ölçüldü. Sketch Engine, milyonlarca sözcükten oluşan metinleri (derlemleri) inceleyerek bir dilin tipik, nadir, olağanüstü özellik ve kullanımlarını tespit etmek için tasarlanan bir yazılımdır.

Türkizmaların kullanım sıklığı ve incelemesi cinsiyet, yaş, doğum yeri, eğitim, sosyal durum, uğraş dili, ikidillilik ve çokdillilik gibi toplumdilbilimsel etkenlere dayanarak sınıflandırıldı. Ayrıca, kesit dil, konu ve bağlama göre anlambilimsel açıdan incelendi. İlk başta Türkizmaların kullanım sıklığı ölçüldü ve kullanıldıkları farklı bağlam ve konulara göre sınıflandırılması yapıldı. Bu ödünçlemelerin kesit dillerine göre gösterdikleri anlam değişmeleri incelendi. Biçem ve kesit dilleri Werlich'in (1983: 270) sınıflandırmasının tamamlanmış hali olan Rugova'nın (2015: 76-81) sınıflandırılmasına göre yapıldı. Bu çerçevede biçemler ve kesit dilleri şu kriterlere dayanarak sınıflandırıldı: a. resmiyet seviyesine göre: özenliözensiz, b. bilgilendirme işlevine göre: teknik ve açıklayıcı-kıyaslamalı, c. teşvik etme işlevine göre: çağrışımcı-değerlendirici, küçümseyici ve ikna edici, ç. anlatımsal işlevine göre; ironik, abartılı ve metaforik biçemler.

\section{Arnavutça türkizmalarının kesit dillerine göre incelenmesi: Kosova sözlü tarihi örneği}

6.1. Nicel incelemenin sonuçları (genel):

Derlem, toplam 10.224 dakika yani 170.4 saat süren konuşmalardan oluşmaktadır. $\mathrm{Bu}$ süre içinde geçen görüşmeler yaklaşık olarak 3000 sayfa transkript metninden ibarettir. Toplam sözcük sayısı iki milyon civarında. Ele alınan konuşmacıların sayısı 98. Görüşmeler soru-cevap şeklinde gelişmekte. Görüşmeyi yapan kişi sayısı bir ila üç arasında değişmektedir. Konuşma, restoran, çay bahçesi gibi açık ve ev, ofis gibi kapalı ortamlarda gelişmektedir. Konuşmacıların çoğunun sosyo-ekonomik statüsü orta. Çobanlık gibi köy meslekleri ve firıncı gibi çeşitli şehir meslekleri ile uğraşan, ilk ve orta eğitimi alan kişilerin sayısı 15'tir. 
Yüksekokul bitirerek öğretmen olan kişilerin sayısı 5, farklı alanlarda üniversite eğitimi alanların sayısı ise 78' dir.

Derlemde 43 kadın ve 55 erkek konuşmacı yer almakta. Katılımcıların yaşı 22 ila 96 arasında değişiyor. Derlemde yer alan katılımcılar, Toskë ve Gegë olmak üzere iki ana lehçe ile Prizren, Drenica, Skenderaj, Priştine, Gilan, Mitroviça, Vuçitırn gibi farklı ağıları kullanıyor. Görüşmelerde, bazen, özenli ve özensiz ayırımı yapılamayacak kadar birbirine yakın resmiyet seviyelerinde konuşmalar kaydedildi. Derlemde kaydedilen türkizmaların toplam sayısı 668. Bu sayı, her yıl devamlı olarak güncellenen Arnavutça Güncel Sözlüğünde yer alan türkizmaların sayısının (1800) \%30'una tekabül ediyor. Kaydedilen sözcüklerin \%7'si her katılımcıda tekrarlanmaktadır. Yaşa göre ve konuşma süresine göre sınıflandırma yapılacak olursa, önce, yaş ilerledikçe katılımcıların sayısının artmasıyla konuşma süresinin de arttığı söylenmeli. Aynı çizgide türkizmaların kullanımında da artış görünüyor. Örneğin, yetmiş yaş üstü katılımcılarda konuşma süresinin artmasıyla birlikte türkizmaların çeşitliliğinin ve kullanım sıklığının oldukça arttığı tespit edilmiştir. Ancak, seksen yaş üstü katılımcıların sayısı ve konuşma süresi önemli ölçüde azalsa da türkizmaların kullanımı aynı oranda azalmadı. Doksan yaş katılımcıları dahil seksen yaş üstü katılımcılarda türkizmaların kullanımı hemen hemen aynı orandadır. Aşağıdaki tabloda, türkizmaların yaşa göre kullanım sıklığı istatistik bilgileriyle birlikte verilmiştir.

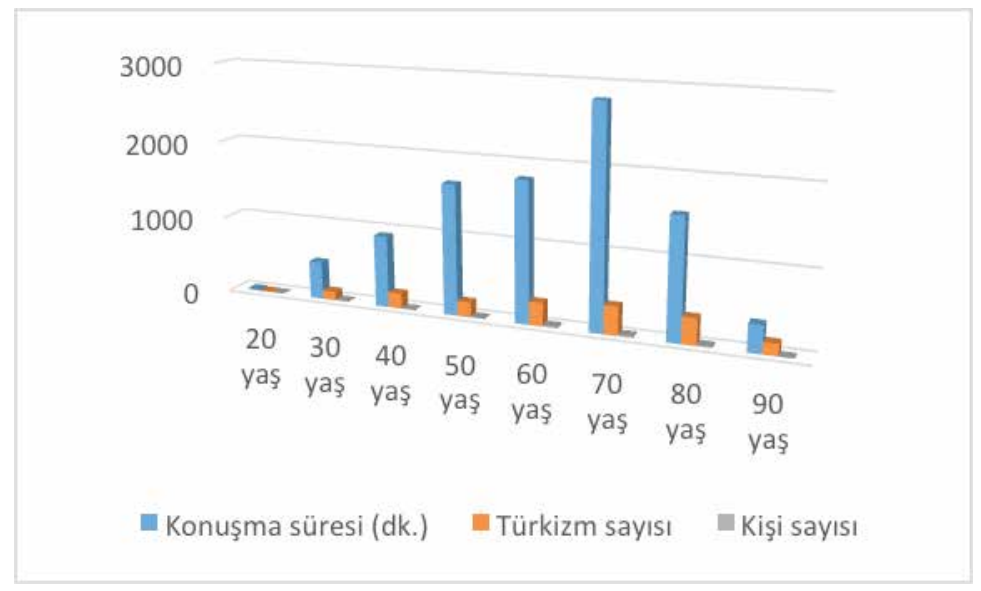

Tablo 1: Türkizmaların kullanımının yaşa ve konuşma süresine göre dağılımı

Derlemde en sık kullanılan 1000 sözcüğün arasında 40 türkizma bulunmaktadır. Yani türkizmalar KST derleminin anahtar sözcüklerinin \% 4'nü oluşturmaktadır. Bu sözcüklerin çoğu aile terminolojisine aittir.13 kişi Toskë lehçesini yani standart dilini kullanırken 84 kişi Gegë lehçesini kullanıyor. Konuşmacıların çoğu iki veya çok dillidir. Konuştukları diller arasında İngiliz, Sırp, Türk ve Alman dili yer almaktadır. Konuşanların arasında şu anda ya da erken yaşta, ev ve mahalle ortamında Türkçe konuşanların sayısı 7'dir. 


\subsection{Nicel incelemenin sonuçları (bireysel):}

Türkizmaların kullanımını hem toplu hem de bireysel düzlemde izledik ve bu çalışmada en uzun ve en tipik konuşmacı türünü teşkil eden Sh. M.'nın yaptığı konuşmayı derlem modeli olarak sunmayı uygun bulduk. Konuşmacı, Türkçenin resmi dil statüsüne sahip olduğu Prizren şehrinde doğup büyüdü. Çocukluğunda aile ortamında konuşulan diller arasında Türkçe de yer almaktadır. Konuşma sırasında hem özenli hem de özensiz kesit dillerini kullanmakta.

Sohbetler, çocukluk konusundan başlayarak profesyonel hayat ve entelektüel konulara doğru ilerledikçe türkizmaların azaldığı tespit edildi. Aslında, bu sözvarlığının aile, yaşam ortamı, tarih, şehir, mimari, ev, bahçe ve mutfak gibi konulardan bahsedilirken kaçınılmaz olduğu görülmüştür. Konuların kronolojik olarak (70-li, 80-li, 90-lı yılları) sınıflandırılmasının türkizmaların dönemlerle paralel bir dağılım gösterdiğini söyleyemiyoruz. Kullanımda dönemden döneme azalma gösterse bile ilk dönem (çocukluk dönemi) diğer dönemlerle k1yaslandığında ortaya çıkan aradaki büyük fark azalmanın aslında dönemle ilgili değil konuyla ilgili olduğunu kanıtlıyor. Dolayısıyla, türkizmaların kullanımı kişinin hayatı boyunca geçtiği dönemlerden çok konulara bağlı olarak fark gösterdiği söylenebilir.

Bahse konu konuşmacının bir diğer dil özelliği, hala, ama, bile (tr. hatta), bash (tr. tam) gibi bağlaçlarını eşanlamlılarıyla birlikte kullanmasıdır. Arnavutça Güncel Sözlügüunde, türkçe kökenli hala kelimesi özensiz konuşma kategorisinde yerleştirilmiştir. Türkçe kökenli hala ve eşanlamlısı ende sözcüklerinin Arnavutça Milli Derlemindeki (AMD) kullanım sıklığı kontrol edilip konuşmacının kullanım oranıyla kıyaslandı. AMD'de kullanım sıklığı daha yüksek olan (8664 defa) ende kelimesinin yerine, konuşmacı AMD'de oldukça düşük (38 defa) kullanım gösteren hala sözcüğünü tercih etmektedir. Bu da, türkizmaların özensiz dilde kullanıldığını doğrulamaktadır. Konuşmacı standart dil değişkesini (Toskë lehçesini) konuşmasa da, mesleği hakkında konuşurken veya siyasi görüşlerini ifade ederken ende sözcüğünü 8 defa kullanıyor. Hala sözcügünü ise toplam olarak 19 defa kullandı. Bu örnek, sözcük tercihinin aslında kesit dilini belirleyebileceğini de düşündürebilir. Aynı şekilde, Türkçe kökenli ama bağlacı da özensiz dil kategorisinde bulunmaktadır ve Arnavutça por sözcüğü ile değiştirilebilir. Türkçe kökenli ama kelimesinin konuşmacı tarafından 16 defa kullanıldığı kaydedildi. Çocukluk ve gençliğindeki özel hayatını anlatırken kullanım sıklığı daha yüksek. Bu bağlamda ama sözcüğü tam 10 defa kullanıldı. Konuşmacının ama sözcüğünü kullandığı kısımlarda konuşma tarzının daha özensiz ve daha rahat, ve duygusal açıdan bir o kadar da derin olduğu tespit edildi. Toplam konuşma süresinin diğer yarısında bu sözcügün kullanımı azalmakta ve sadece 6 defa kullanılmakta. Konuların ciddiyeti ve resmiyeti daha yüksek seviyeye yükselirken ama sözcüğü yine kişisel hayatından diyaloglar, mesafeli tarzdan samimi tarza geçtiği sıralarda tespit edildi. Bu sözcüğün eşanlamlısı olan por (tr. fakat, ama) bağlacı ile kıyaslanacak olursa oldukça az kullanıldığı söylenebilir. Büyük çoğunlukla özenli ve mesafeli tarz ifadelerde ve üçüncü kişiler hakkında ya da kamuoyunu ilgilendiren ciddi konular hakkında konuşurken görülse de özensiz tarzda da eşit derecede kullanıldığı tespit edildi. Bu da özenli dilin özensiz dile etkisinin bir göstergesidir. Aslında kesit dillerin birbiriyle örtüştüğünün de bir kanıtıdır. Ama ve por sözcüklerinin aynı cümle içinde kullanıldığı da tespit edildi. Bu tür kullanımların sebepleri türkizmaların anlambilimsel açıdan incelenmesi bölümünde ele alındı: 
(3) “Ama ky është rast se ka mbijetu, ka mujtë pjesërisht edhe mu pasuru, por edhe me metë e pavarur prej ndikimeve ose me ra në ndikime tjera ose me ringjallë nacionalizmin ose çka po di. Neve studentët kemi qenë si në hava (qeshë)." (SH.M. Transkript s.24) // tr.: 'Ama bu yüzden hayatta kalabildi, kısmen zengileşebilirdi de, fakat dış etkenlerden bağımsız da kalabilirdi veya başka etkilerin altında kalabilir veya milliyetçiliği veya bilmem neyi uyandırabilirdi. Biz öğrenciler sanki havadaydık (desteksiz, güçsüz) (gülüyor)'

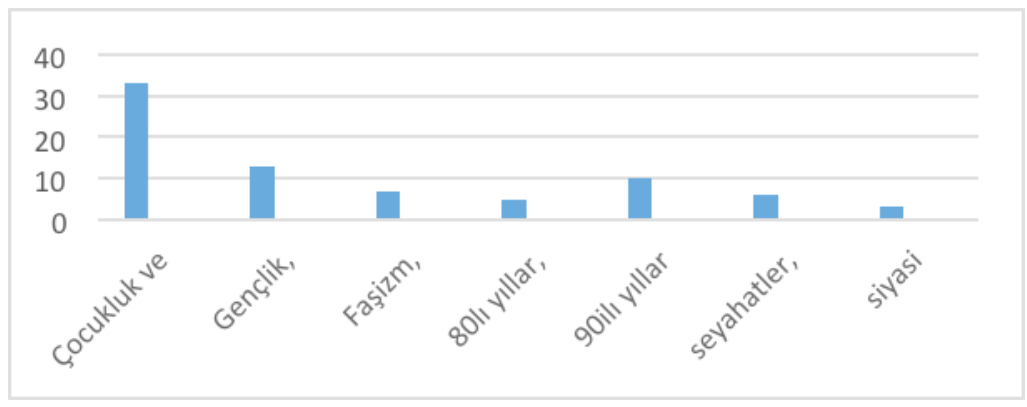

Tablo2: Örnek bireyin kullandığı türkizmaların konu ve dönemlere göre dağılımı

\subsection{Nitel incelemenin sonuçları}

A. Sonuç olarak, resmiyete göre değerlendirildiğinde konuşmacıların çoğunun görüşme sırasında başladıkları resmiyet seviyesini değiştirmedikleri görüldü. Resmiyet seviyesi her zaman standart değişkenin kullanımı ile belirlenmiyor. Standart değişke kullanılmadığı durumlarda da resmiyet seviyesini yüksek tutan konuşmacılar vardır (Örneğin, Priştine Üniversitesi Rektörü M.D. Gegë lehçesini kullansa da konuşmasını özenli bir biçemle sürüdürüyor). Aynı zamanda, özenli konuşmadan özensiz konuşmaya geçiş gösteren kişilerin sayısı da az değildir. Dolayısyla, resmiyet seviyesine göre değerlendirildiğinde türkizmaların, bilinçsiz olarak, her iki seviyede eşit şekilde kullanıldığı tespit edildi. Ancak, belli birtürkizma kullanıldı̆̆ 1 vakit 'bizim eskiden dediğimiz gibi', 'siz bilmezsiniz...' ya da 'halk arasında dendiği gibi..' tarzı açıklama yapma gerekliliğini duyan konuşmacılar da var. Örneğin: 'unë jam më i riu, sugar si i thuhet te shqiptarë (...ben (ailenin) en küçüğüyüm, biz Arnavutların da dediği gibi 'sugare’4). Konuşmacı, açıklamayı sözcüğün Türkçe kökenli olduğu için değil eskimiş veya kendi bölgesine has olduğunu, genç kesimin anlayamayacağını veya konuya aşina olmadığını düşündüğü için yapmaktadır. Burada, görüşmeyi yapan kişilerin yirmili yaşlarda olduğunu ve meshliçe (tr.meclis, toplantı) gibi eskimiş sözcük hariç başka hiçbir sözcük hakkında açıklama gereği duymadığını vurgulamak gerekir.

B. Bilgilendirmeye yönelik teknik ve açıklayıcı-kıyaslayıcı biçemler kullanılırken, konuşmacının dil tercihleri konunun kapsadığı kavramlarca yönlendirilir. Derlemde kaydedilen bu tür biçemlerde iç mekan, yemek, mimarlık, silah v.b. gibi özel terminolojiyi oluşturan ve Arnavutça sözcükleriyle değiştirilemeyecek birçok türkizmadan örnekler tespit edildi: abdes (abdes), çarshaf (çarşaf/baş örtüsü, hicab), aksham (akşam namazı), xhuma (cuma namazı), odë (aile büyüklerinin veya köyün önde gelenlerinin toplandığ 1 alan/meclis), tenxhere (tencere), tepsi (tepsi), çarshi (çarşı, Osmanlı mimarisi tarzında olan çarşı), imaret (imarethane), 
islihat (savaş kampı), teqe (tekke), allti (altı mermili ateşli silah), kundak (tüfek gibi bazı ateşli silahlarda bunları çeşitli yönlere çevirmeye yarayan, namlunun altında bulunan ağaç veya metal bölüm) dimgjik (dipçik), şarki (müzik enstrümanı), çifteli (iki telli müzik enstrümanı), lahuta (müzik enstrümanı) vs. Ancak, derlemde, yeni teknolojiler, siyaset, bilişim, tasarım gibi bilim alanlarından bahsedilirken türkizma içeren konuşmalara rastlanmadığı tespit edildi.

\subsection{KST derleminde kullanılan türkizmaların anlambilimsel özellikleri}

\subsubsection{Sözcüksel ve biçemsel olgular}

Kesit dili anlamsal bir kavramdır. Kesit dili, belirli bir duruma ya da toplumsal bağlam ile ilgili anlamlar konfigürasyonudur. Dolayısıyla, bu anlamları gerçekleştirecek tipik ifadeler, sözcüksel ve dilbilgisel özelliklere sahiptir. (Halliday,1989: 27). Bu açıdan baktığımız zaman türkizmaların anlambilimsel açıdan ayrı başlık altında incelenmesinin önemini anlıyoruz. Bu yüzden, inceleme yöntemlerinde (3. bölümde) bahsettiğimiz kesit dil sınıflandırılmasının son iki kategorisinde yer alan biçemlere türkizmaların anlambilimsel özelliklerinden bahsederek ele alındı. Türkizmalar, ödünçleme süreci sırasında ve Arnavutçaya yerleştikten sonra birçok anlam değişimine uğramaktadır. Anlam daralması, anlam genişlemesi, iyileşmesi, kötüleşmesi gibi birçok süreçten geçmektedirler. Burada, çalışmamızın özlülüğünü korumak amacıyla bu konuların üzerinde fazla durmadan sadece biçemsel ve anlamsal olgulardan bahsedeceğiz.

Türkizmaların biçemsel ve anlamsal süreçleri dediğimiz zaman, aslında eşanlamlılarının eşbağımlı kullanım şekillerini kast etmekteyiz. Bahse konu süreçler, eşanlamlılar, eşsözler ve söz uzatımı aracılığıyla ifade edilen dizimsel (sentagmatik) ilişkilerdir. KST derleminde tespit edilen deyişbilimsel kullanımlar yani içinde türkizmaların bulunduğu deyimler, onların anlatımsal işlev yapan biçemlerde kullanıldı̆̆ını gösterir.

Vajzoviç'e göre 'eşanlamlıların eşbağımlı kullanımları, dilbilimsel, toplumdilbilimsel veya deyişbilimsel sebeplerden dolayı gerçekleşmektedir.' (Vajzoviç,1999: 204)

Böyle bir olgu, deyişbilimsel ve anlambilimsel bağlamda, konuşmacının

a. aynı veya benzer anlamı ifade eden sözcük birimlerini yinelemekten kaçınıp, bu şekilde anlatım tarzını tazelemeye ve güzelleştirmeye, hatta daha net ve açıklayıcı bir şekilde söze dökmeye çalışması (1)

b. aynı ya da benzer anlam taşıyan farklı sözcük birimlerini yinelemekle belli bir anlamı sadece işaretlemek, netleştirmek ve tamamlamakla kalmayıp daha derin bir şekilde yaşamaya ya da içselleştirmeye çalışması ile açıklanabilir.

Yukarıdaki sebepler, anlatım diziminde eşsöz (pleonasm) ve söz uzatımı (tautology) şeklinde ortaya çıkabilir. Bu iki olgunun ortak özelliği aynı sözcüklerin tekrarlanıyor olmasıdır. Her ikisi anlatımsal ve biçemsel ya da deyişsel araç olarak kullanıldığ için aralarındaki farkı kesin olarak tespit etmek her zaman kolay değildir. Totoloji ${ }^{5}$ ya da söz uzatımı 'bir kavramı aynı anlamda sözcüklerle anlatma, bir sözcük ya da düşünceyi benzer sözcüklerle yineleme’ olarak tanımlanırken pleonazım (Vajzoviç, 1999: 206) ya da eşsöz, anlam içeriğinin kısmen yinelenmesi yani bir kere söylenen bir şeyin tekrar, bazen de sebepsiz yere, anlatılması olarak tanımlanır. Totoloji bir deyiş ve anlambilimsel kategori olarak bağlamda, anlatım diziminde 
eşanlamlıların bağlaçsız yani virgül kullanarak ve bağlaçlı olmak üzere iki farklı şekilde belirir:

Derlemde rastladığımız eşanlamlıların bağlaçlı ve bağlaçsız kullanımları aşağıdaki tablolarda görülebilir:

\begin{tabular}{|ll|l|}
\hline 1. & ..ato adete, tradita & (tr.) o adetler, gelenekler... \\
\hline 2. & ..pa busull, pa kompas .. & (tr.) ..pusulasız, pusulasız.. \\
\hline 3. & ..defa ata i thojshin dajre.. & (tr.) defler, onalar onlara dayre diyordu.. \\
\hline 4. & ..ka ni fidan, ka ni lule.. & (tr.) bir fidan(yeni yetişmiş çiçek), bir çiçek var.. \\
\hline 5. & po, jeshiltë, si e gjelbërt & (tr.) evet, yeşil, yeşil gibi \\
\hline 6. & ..me kollomoq, me misër & (tr.) mısırlı, mısırlı \\
\hline 7. & ..nji muhabet, nji tregim & (tr.) ..bir muhabbet, bir hikaye \\
\hline 8. & ..te pazari, te tregu & (tr.) pazarda, pazarda (türkçe ve arnavutça \\
\hline 9. & ..njifar deal (ing.), njifar pazari & (tr.) bir çeşit anlaşma, bir çeşit pazarlık \\
\hline 10. ..jam ul në skej, në qosh & (tr.) ..bir uçta, bir köşede oturdum \\
\hline 11. ..po lyp pjeshka, shefteli & (tr.) şeftali, şefteli istiyorum \\
\hline 12. & Keni bo naj qeder, naj kader & (tr.) bir zarar verdiniz, bir yanlış yaptınız \\
\hline 13. & ..jo ilaçat, jo barnat & $\begin{array}{l}\text { (tr.) ..ilacıydı, (m)ilacıydı (şuydu, buydu } \\
\text { anlamında) }\end{array}$ \\
\hline
\end{tabular}

Tablo 3: Eşanlamlıların bağlaçsız (virgüllü) eşbağımlı kullanımları

\begin{tabular}{|l|l|}
\hline 1. Adetet e zakonet tradicionale & Geleneksel adet ve gelenekler \\
\hline 2. Njerëzit me din e iman (deyiş) & Dini imanı olan insanlar \\
\hline $\begin{array}{l}\text { 3. Potere e gjurulldi (që thotë mileti } \\
\text { ynë) }\end{array}$ & $\ldots$ (halkımızın deyimiyle) patırtı ve gürültü \\
\hline
\end{tabular}

Tablo 4: Eşanlamlıların bağlaçlı kullanımları

Bazı örneklerde sözcük değil cümle tekrarı görüldü:..i rah, $i$ sakaton - (tr.) dövdü, sakatladı

Yukarıda da söylediğimiz gibi plönastik ifade deyince, genelde, anlam içeriğinin kısmen tekrarlanması kastedilir. Bu tür bir kullanım şu örnekte tespit edildi: ..ka qenë i zidum $d u$ vari. (tr. duvar yapılmıştı). 'Yapma' ya da inşa etme anlamını taşıyan 'zidum' eylemi slav kökenli bir ödünçlemedir ve kelime kökünde yine duvar anlamını içermektedir (söz be söz çevirisi:duvar edildi). 
Tablo 3 'teki örneklerin bazılarında yer alan ve Arnavutçaya yerleşmiş türkizmalar, geçirdikleri anlam değişimleri yüzünden kaynak dilde (Türkçede) taşımadıkları anlamlarla Arnavutça sözcüklerin eşanlamlıları olarak kullanılmaktadır:

(4).. gjithë verës kemi ushtruar në bahçe, i themi ne, në kopsht nën hijën e mollës // (tr.) yazın biz ona bahçe diyoruz, bahçede elma ağacının gölgesinde çalışıorduk

(5)..si të varfën, si gjynaha //

(tr.) yoksullar gibi, zavallılar gibi

(6)..rrugë ish e paasfaltuar, xhade //

(tr.) yol döşenmemişti, caddeydi

(7).. xhama e qelqit //

(tr.) cam cam 1

Örnek (4)'teki bahçe sözcüğü sadece meyve ve sebze yetiştirilen yer olarak kullanılır. Örnek (5)'teki gjynah (tr.günah) sözcügü adlaştırma sürecinden geçip zavallı anlamını kazandı. Örnek (6)'daki xhade (tr.cadde) sözcügüü sadece döşenmemiş yol anlamında kullanılır. Örnek (7)'deki xham (tr.cam) sözcüğü gereksiz yere tekrarlama örneğidir.

Türkizmalar Arnavutçanın bazı eksiltili yapılarında (ellipsis) ${ }^{6}$ da kullanılır. BU yapılar, derlemde tespit edilen aşağıdaki örneklerdeki gibi tutumluluk, biçem vb. nedenlerden dolayı kaynaklanır:

(8) Për të fal (namazin e) xhenazen

(tr.) Cenazeyi kılmak/ cenaze namazını kılmak yerine

(9) Falet (namazi i) bajrami

(tr.) Bayram kılınıyor/ Bayram namazı kılınıyor yerine

\subsubsection{KST derleminde türkizmaların deyim bağlamında kullanımı}

Türkizmalar, büyük ölçüde, kalıplaşmış söz öbeklerinde kullanılır. KST derleminde bu tür söz öbekleri bëj (yapmak), jam (olmak) gibi yardımcı fiillerin yardımıyla oluşan örneklerde kaydedilmiştir. Deyimsel yapılar ise özel bir yapı türü olarak sözlüklerde de yerleştirilmektedir. 'Anlambilim ışı̆̆ında tanımlanacak olursa deyimler, uzun süreli kullanımdan dolayı gerçek anlamsal değeri haline gelen özel ve uyarlanmış bir anlam taşıyan söz öbekleridir denilebilir. Bu tür sözler, asıl anlamın içinden kaynaklansa da kaynaklanmasa da uygun bağlamlarda deyim haline gelmektedir.' (Vajzoviç, 1999: 209) Deyim birimleri kalıplaşmış söz kümeleri olduğu için sözcük sıralaması değiştirilemez. Konuşma dilinde bu tür yapılar ayrılmaz bir bütün olarak üretilir. Aşağıda, KST derleminde kaydettiğimizsöz öbeklerini, deyimleri ve mecazi anlam taşıyan bazı örnekleri Türkçe anlamlarıyla birlikte gösterdik:

Për hajr koftë (tr.hayırlı olsun), njerëzit me din e iman (tr. dini imanı olan insan/ insaflı, haysiyetli kişi), ja me hatër ja me luftë (iyilikle ya da kötülükle, ne olursa olsun gerçekleşecek), m'ra në hise (birinin payına düşmesi/ birinin sorumluluğunun başkasına düşmesi), nxjerr nji pare për idare (geçimi sağlamak), inati m'vike (bir olayı kabul etmekte zorlanmak/ inadına gelmek), m’u bo kurban (bir şey uğruna kendini feda etmek), nuk na shkon muhabeti (muhabbetimiz gitmiyor/aramız iyi değil), dita e re nafaka e re (yeni gün yeni rızk), bëj iftarin (orucu açma eylemi), bojn llaf (konuşuyorlar/dedikodu yapıyorlar - anlam kötüleşmesi), jem bo ortak (bir konuda işbirliği yapmak), ditë pazari (eskiden şehrin meydanında alışveriş yapıldığı gün), keni bo naj qeder (bir şeye zarar vermek), rahmet shpirti (rahmetli, merhum), jon dal n'sabah qefi (sabah keyfine kalktılar), u pjektë në xhehnet (cehennemde yanasin), me xhepat bosh kemi ecë (cebimiz boş geziyorduk/ çıkarsız), e ka zanat ato (anlam kötüleşmesi/ 
genelde kötü işlerle meşgul olmak), ështënë zor (zor durumda olmak), s'ki zorme...(birşeyi yapmak zorunda olmamak), ndreqja samarin mire atij (birine semerini vurmak/yerini göstermek), sari si dylli (çamsakızı gibi sarl/soluk, benzi soluk), jepsha zor (bir işin olması için gayret göstermek/uğraşmak), me zor (zorla,zoruna), hi në qef (birinin beğenisini kazanmak/ beğenmeye başlamak), kam qef (yapmak istemek), i kom qef (beğenmek/sevmek), me të njejtin avaz (aynı avazla/aynı şekilde devam etmek/bir şeyi tekrarlamak), politika është e sakatume (siyaset zarar görmüş), kundra neve e kundr hamomit (bize ve filan kötü kişiye karş1/ burada hamam sözcüğü anlam kötüleşmesi sürecinden geçti), babai im është jataku i tyre (söz be söz çevirisi: 'babam onların yatağıydı'/babam onlara yataklık yaptı), dynjenë ka me bo kahre (dünyayı kahredecek/herkese zor anlar yaşatacak), kiametin e bojke (bir şeye çok kızarak bağırıp çağırmak, feryat etmek),dita e kijametit (kıyamet günü),kurdis xhenazen (cenaze merasimini hazırlamak), ka pas nji lezet jeta (hayatın bir güzelliği/bir tadı vardı), bojsha me lezet (memnuniyetle yapıyordum), den baba den (oldum olalı, çok eski zamanlardan beri, ezelden beri/ 'dededen, babadan' (Dizdari, 2005:204,) vs.

Türkizmaların anlamsal özelliklerinden bahsederken başka bir dil olgusunu daha anmak gerekir. Bir grup ödünçlemenin kaynak dildeki şekil ve anlamları erek dilin sistemi ile uyum sağlamadığı görülmüştür. Bu tür sözcükler kaynak dilden erek dile çevrilebilecek türden sözcüklerdir. Fakat, dilsel sebeplerden çok dil dışı sebeplerden dolayı ödünçleme sürecinin ilk aşamasında çevirinin yapılmadığı ve erek dile olduğu gibi yerleştiği görüldü. Bu tür kullanımlara genelde dini bağlamlarda veya günlük yaşamdan örneklerde rastlanmıştır: Allahile (tr. allah aşkına), mozallah (maazallah/tanrı korusun, tanrı esirgesin), ishalla (inşallah/tanrı isterse/umarım), hoshgeldiniz (hoşgeldiniz), hajdeni (hadisenize!), hajde bujrum (hadi buyurun!), hilaf-hilaf (tr. gruplar halinde). Burada fi-sebil-al (hiçbir karşılık beklemeden) deyimi de ilave edilebilir. Bu kelimeyi bağlamıyla birlikte göstermekte fayda vardır: ' ...domethanë ishte ajo dashuria pak artificiale. Nuk ishte ajo krejt qe thojmë na fise-bile-al për zotin.' (.. yani o sevgi biraz yapmacıktı. Allah için dediğimiz $f$-sebile-al değildi.) Buradan, konuşmacının doğru yerde kullansa da deyimin tam anlamını bilmediği görülebilir.

$\mathrm{Bu}$ grup ödünçlemelerin arasında yer alabilecek ve sıkça kullanılan şu deyimlere de rastlandı: vallai/vallahin/vallahi (vallahi), demek/medemek (demek ki/yani), kysmet/kësmet (kısmet), mashalla (maşallah) ve nejse (neyse).

Anlatımsal açıdan daha güçlü ifadeler kullanabilmek için konuşmacıların Türkçe eklerin yardımıyla Arnavutça kökenli sözcüklerden oluşan, hibrid, yani hem kaynak ve erek dilden alınan unsurların birleşimiyle oluşan (Jaşar-Nasteva, 1998:36) türkizmaları kullandığ tespit edildi:

-li eki,sabërli (sabırlı), borxhli (borçlu), kasabali (şehirli), merakli (meraklı), Prishtinali (Priştineli) örneklerinde görüldü.

-lerë çoğul eki, genellikle aile üyelerinin çoğul şeklini ifade etmek için kullanıldı: axhallarë (amcalar), baballarë (babalar), mixhallarë (amcalar), agallarë (ağalar), dajallarë (dayılar), xhaxhallarë (amcalar), pashallarë (paşalar), beglerë (beyler), shehlerë (şeyhler). $\mathrm{Bu}$ ek sadece ailenin erkek üyeleri için kullanılır, kadın üyelerinde kullanıldığı görülmemiştir. 
-gji/-xhi/-çi eki, bir işi ya da sanatı meslek edinen kişiyi adlandırmak ve adlara ve bazı sıfatlara gelerek bir şeye alışkanlığı, bir şeyi huy edinmeyi gösteren alışkanlık sıfatları yapmak için kullanılır (Korkmaz, 2009: 41). Bu ek Arnavutça kökenli sözcüklere eklendiğinde ironi ve küçümseme anlamını katan sözcüklerin türetildiği ve dolayısıyla Arnavutça sözvarlığının içinde güçlü bir anlatımsal araç olarak görev alan örneklerde yer aldığı görülmüştür: ambëltorgji (tatlıc1), bahçebanxhi (bahçıvan), bërllogxhi (gübreci), duhanxhi (sigara içen), dajrexhi (daire çalan), gurbetgji (gurbetçi), furraxhi (fırınc1), interesgji (çıkarc1), jorganxhi (yorganc1), jabanxhi (yabanc1), kafexhi (kahveci), kavgagji (kavgac1), maqinagji (makineci), poresçi (vergi memuru), qiragji (kiracı), sahatçi (saatçı), zhurmagji (gürültücü, velveleci).

-llëk/-llak: refugjatllëk (mültecilik), qyqarllëk (korkaklık), bajraktarllëk (bir işin öncüsü olma), bashkallak (birlikte, birliktelik), bollëk (bolluk), boshllak (boşluk, eksiklik yoksunluk duygusu), hajlazllëk (haylaz olma durumu), fukarallëk (yoksulluk, güçsüzlük), haxhillëk (hacı olma durumu), infermierllak (hemşirenin yaptığı iş, hemşirelik), masterllak (yüksek lisans), njerëzillëk (insanlık), obërlluk (üniforma, kalın önlük), ustallëk (ustalık), vëllazerllak (kardeşlik).

-çe eki: popullorçe

Sonuç olarak, teşvik edici işlevi açısından biçem veya kesit diller açısından türkizmaların çağırışımcı, değer verici, küçümseyici ve ikna edici olmak üzere dört biçem türünde de kullanıldığ 1 tespit edilmiştir. Burada çağırışımcı biçemin belirli bir grubun hazır bulunmasını gerektirdiğini hatırlatmak gerekir. Derlemdeki bu tür kullanımlar, genelde din bağlamında ya da muhatabın islam dinine mensub olmasını gerektiren konuşmalarda görüldü. Örneğin: abdes, selam, sure, xhenaze, xhuma, teqe, shehlerë, tyrbe, ziqr, shehadet, sheit,allahile, ashk, ferexhe, fisebilal, haxhillëk, imam etj. Değer verici ve küçümseyici biçem kullanılırken -gji/xhi ve -llak eki ile oluşan hibrid sözcüklere rastlandı. Bu Türkçe eklerinin sahip olduğu anlatımsal işlevlerinden dolayı, türetikleri sözcüklerin Arnavutça sözcükleriyle değiştirilemeyeceğini gösterir. İkna edici biçem kullanılırken ise türkizmaların kullanıldı̆̆ 1 en tipik örnekler bağlaçlar ve deyimlerdir: 'hatta' anlamında kullanılan bile ve bile bile, allahile, mazallah, ishalla, vallahi v.s.

\section{Sonuç}

KST derleminde 600'den fazla türkizma kayedildi (Ek’te derlemdeki türkizmaların listesi verilmiştir). Büyük bir kısmı(184 sözcük) Arnavutça Güncel Sözlügünde yer almamasına rağmen konuşma dilinde sık sık duyulabilen sözcüklerden ibarettir. Sözcüklerin önemli bir kısmı Türkçe ekleriyle oluşmaktadır. Dolayısıyla, bu eklerin Arnavutça dilbilgisinde üretken ve aktif ekler arasında yer alması gerekir.

Arnavutça özenli dil değişkesi özensiz konuşma dili ile gitgide örtüştüğünden dolayı türkizmalar her iki kesit dilinde kullanımını korumaktadır. Özellikle metaforik, ironik gibi anlatımsal görev yüklenen biçemlerde güçlü bir ifade aracı olan türkizmalar, Arnavutçanın özenli dil değişkesindeki aktif kullanımını canlı tutmakta. (Ör. kiyamet, denbabaden - oldum olalı). Bunun örneklerini standart lehçeyi kullanmayıp özenli dil değişkesini kullanan konuşmacılarda gördük. 
Ayrıca, özenli dil değişkesini kullanan bazı konuşmacılarda türkizmaların kullanımı her ne kadar en aza inse de, bilgilendirmeye yönelik teknik ve açıklayıcı-kıyaslayıcı biçemler kullanılırken belirli konularda kullanılmaları şarttır. Çünkü, aile, ev, mahalle, şehir, müzik, tasavvuf, din, çeşitli araç ve gereçler gibi özel terminoloji oluşturan sözcüklerdir. Örneğin: babë (baba), sharki (bir çeşit müzik aleti), ziqr (bir tarikata bağlı olanların Tanrı'nın adını ard arda söylemesi), çarshi (çarşı), dysheme (döşeme) v.b. Bu sözvarlığının çoğu, Arnavutça karşılıkları olmayan ya da onların yerinde kullanılan sözcüklerin duygusal ve entelektüel düzlemde konuşmacıyla ilişki kurulamayan türden sözcükler olduğu için değiştirilmesi zor ve hatta imkansız olan sözcüklerdir.

Türkizmalar, ödünçleme süreci içinde uğradıkları anlam değişiklikleri yüzünden (4), (5), (6), (7), (8), (9) ve farklı bağlam ve kesit dillerinde gösterdikleri anlam çeşitliliği yüzünden Arnavutça sözcükleri ile değiştirilemez. Türkizmaların başka sözcüklerle değiştirilmesini bir sözcüğün birden fazla kesit dilinde gösterdikleri aktif kullanım yüzünden de imkânsızlaşmaktadır.

\section{Notlar}

1 Bu eserler, Türkçe, Arapça ve Farsçanın etkisi altında gelişen bir Arnavutçayla yazılan Divan Edebiyatı türünden eserlerdir. Bazı araştırmacılara göre Arnavutçadaki türkizmaların bu eserler üzerinden incelenmesinde fayda vardır. Diğerlerine göre ise aslında, 'beytecilerde çok fazla şark kökenli yabancı sözcük yoktur,(...) Arnavutça sözvarlığının genel durumu hakkında bir kanıt oluşturmaz.' (Lloshi, 2015, Perla. s. 23-27)

2 https://www.ethnologue.com/about/language-status bknz. Ethnologue dilbilimi alanında öncü SIL International tarafindan yetkilendirilmiştir.

3 Arnavutça Milli Derlemine ulaşmak için şu linke bakınız: http://web-corpora.net/AlbanianCorpus/search/common -search-start-en.html

4 Sugar sözcüğü Arapça kökenli Osmanlıcada küçük, küçük çocuk, buluğa ermemiş çocuk, anlamını ifade eden sagir sözcüğünün çoğul şeklinden türemiştir. Arnavutçada ailenin en küçük çocuğu anlamında kullanılır.

5 Çalışmadaki dilbilimi terimleri İmer, K. vd.'ne ait Dilbilim Terimleri (2011)'e dayanarak kullanılmıştır.

6 Tümcede kimi öğelerin silinmesi, eksik olması ya da kullanılmaması; ör. Şekeri/kalbi var (Şeker/kalp hastalı̆̆ı var yerine).

\section{Kaynaklar}

Aksan, D. (2003). Her yönüyle dil. Ankara: Türk Dil Kurumu.

Aronoff, M. (1985). Orthography and linguistic theory. Language, (pp. 28-72) Language Society of America.

Demiraj Sh. (2013). Gjuha shqipe dhe historia e Saj, Akademia e Shkencave të Republikës së

Shqipërisë. Tiranë: Onufri.

Dizdari, T. (2005). Fjalor i orientalizmave në Gjuhën Shqipe. Tiranë:AIITC.

Friedman, V. (2002). Macedonian. Skopje: Lincom Europa .

Douglas, B. and Finegan, E. (1994). Sociolinguistic perspective on register. New York \&Oxford:

Oxford University.

Halliday, M.A.K. (1990). Spoken and written language. New York: Oxford University.

Halliday, M.A.K. and Hasan, R. (1989). Language, context and text: Aspects of Language in a Social-Semiotic Perspective. New York \& Oxford: Oxford University.

İmer, K. ve diğ. (2011). Dilbilim sözlüğ̈̈. İstanbul: Boğaziçi Üniversitesi. 
Jašar-Nasteva, O. (1998). Kontaktet gjuhësore në hapësirat Ballkanike. Shkup:Logos-A.

Krajni A., (1965), Hymja e turqizmave në shqipen dhe përpjekjet për zëvendësimin e tyre. Studime Filologjike. No.1, pp.143-151.

Korkmaz, Z. (2009). Türkiye Türkçesi grameri- Şekil dilbilgisi. Ankara: TDK.

Reinkowski, M. (2002). Kulturerbe oder erblast? Zum status der turzismen in den staaten südosteur pas, insbesondere des Bosnischen. Mediterranean Language Review 14. Wiesbaden: Harrassowitz Verlag.

Rugova, B ve Rugova, L.S. (2015). Hyrje në gramatikën e tekstit të gjuhës shqipe. Prishtinë: Trembelat. Rugova, L. (2017). The formal and informal status of Turkish ioanwords in Albanian. Trakya Üniversitesi Edebiyat Fakültesi Dergisi (VII (13) cilt). ss. 225-234.

Vajzović, H. (1999). Orijentalizmi u književnom djelu (Lingvistička analiza). Sarajevo: Orijentalni Institut.

Wierzbicka, A. (1999). Semantics primes and universals. New York: Oxford University.

Xhanari, L. (2012). Turqizmat dhe semantika e tyre në fjalorët e shqipes. Tiranë: Botimet Dudaj.

\section{Elektronik kaynaklar}

http://oralhistorykosovo.org/?s=h

http://web-corpora.net/AlbanianCorpus/search/common-search-start-en.html

http://www.fjalori.shkenca.org/

https://www.sketchengine.eu/ 